\title{
Role of aryl hydrocarbon receptor in central nervous system tumors: Biological and therapeutic implications (Review)
}

\author{
MONTSERRAT ZARAGOZA-OJEDA ${ }^{1,2}$, ELISA APATIGA-VEGA ${ }^{1}$ and FRANCISCO ARENAS-HUERTERO ${ }^{1}$ \\ ${ }^{1}$ Laboratorio de Investigación en Patología Experimental, Hospital Infantil de México Federico Gómez, \\ Mexico City 06720; ${ }^{2}$ Posgrado en Ciencias Biológicas, Facultad de Medicina, Universidad \\ Nacional Autónoma de México (UNAM), Mexico City 04510, México
}

Received January 28, 2020; Accepted January 25, 2021

DOI: $10.3892 / \mathrm{ol} .2021 .12721$

\begin{abstract}
Aryl hydrocarbon receptor (AHR) is a ligandactivated transcription factor, whose canonical pathway mainly regulates the genes involved in xenobiotic metabolism. However, it can also regulate several responses in a noncanonical manner, such as proliferation, differentiation, cell death and cell adhesion. AhR plays an important role in central nervous system tumors, as it can regulate several cellular responses via different pathways. The polymorphisms of the AHR gene have been associated with the development of gliomas. In addition, the metabolism of tumor cells promotes tumor growth, particularly in tryptophan synthesis, where some metabolites, such as kynurenine, can activate the AhR pathway, triggering cell proliferation in astrocytomas, medulloblastomas and glioblastomas. Furthermore, as part of the changes in neuroblastomas, AHR is able to downregulate the expression of proto-oncogene c-Myc, induce differentiation in tumor cells, and cause cell cycle arrest and apoptosis. Collectively, these data suggested that the modulation of the AhR pathway may downregulate tumor growth, providing a novel strategy for applications for the treatment of certain tumors through the control of the AhR pathway.
\end{abstract}

\section{Contents}

1. Background of AhR research

2. A glance at $A H R$ molecular features

3. AHR-associated proteins

4. Canonical AhR pathway

5. Direct interactions between AHR and other proteins

Correspondence to: Dr Francisco Arenas-Huertero, Laboratorio de Investigación en Patología Experimental, Hospital Infantil de México Federico Gómez, 162 Calle Dr. Márquez, Colonia Doctores, Mexico City 06720, México

E-mail: farenashuertero@yahoo.com.mx

Key words: brain tumors, astrocytoma, medulloblastoma, neuroblastoma, aryl hydrocarbon receptor
6. Non-canonical AhR pathway

7. Potential therapeutic applications of the crosstalk between AhR pathway and central nervous system tumors

8. Conclusions

\section{Background of AhR research}

The study of AhR can be discussed from two standpoints; the first one reflects the reality of current times, that is, human exposure to synthetic organic compounds and the consequences that has on human health. During the 1970s, the studies of several toxicologists, biochemists and molecular biologists focused on the toxic effects of 2,3,7,8-tetrachlorodibenzo-p-dioxin (TCDD), a polychlorinated dibenzo-p-dioxin that was identified as an unintentional by-product of the herbicide 2,4,5-trichlorophenoxyacetic acid synthesis (1). Individuals who worked in the manufacturing of this herbicide suffered diseases such as porphyria cutanea tarda and chloracne (2). It was proven by a later study that TCDD exposure was the cause of porphyria in such workers, which acted by increasing the activity of the initial enzyme in heme biosynthesis, $\delta$-aminolevulinic acid synthetase (3).

The second standpoint is the rather accidental finding of certain studies from the early 1950s showing that tumor development was inhibited in rats exposed to the carcinogen 3-methylcholanthrene (3-MC) when it was administrated simultaneously with other carcinogens (4). It was later proven that this inhibition of carcinogenesis can be induced not only by $3-\mathrm{MC}$, but also by a great variety of polycyclic aromatic hydrocarbons (PAH), as these compounds impede the action of an enzyme that modifies carcinogens, nowadays known as cytochrome P450 family 1 subfamily A member 1 (CYP1A1), a member of the cytochrome P450 family (5). Later, in 1969, that modifying activity was named $\mathrm{Ah}$ hydroxylase $(\mathrm{AHH})$ and certain studies revealed that in some, but not all, syngeneic strains of mice, this enzyme activity was induced by PAHs $(6,7)$, which suggested the existence of a gene that controls $\mathrm{AHH}$ activity, termed the Ah locus $(8,9)$. The Ah locus was then found to be involved in the regulation of carcinogenicity, mutagenicity and toxic responses to PAHs (10). This created an opportunity to examine other types of toxic compounds, such as TCDD and 3-MC; the results showed that TCDD was 30,000 times more potent in inducing 
AHH activity than 3-MC (11). Therefore, TCDD became the ideal molecule for testing the activity of the Ah locus (12).

The study of steroid receptors was also increasing at the time; with this in mind, the idea of a 'receptor' that controls the Ah locus emerged, which may also explain the greater affinity for certain compounds, such as TCDD, over others, such as 3-MCA (13). The first radioactively labeled TCDD [(3H)TCDD)] was synthetized, and finally the existence of a receptor was confirmed in 1979 and the term AHR was used for the first time (14). Unexpectedly, only a fraction of $(3 \mathrm{H}) \mathrm{TCDD}$ bound to the receptor in the cytoplasm as expected, but another portion bound to the receptor in the nucleus, as described for the steroid receptors. Shortly after AHR discovery, it was determined that the weight of the receptor varied depending on its origin; when it was isolated from the cytoplasm it was heavier than when found in the nucleus $(15,16)$. This fact aroused interest regarding other proteins associated with the receptor, and their role in its function. A few years later, a protein was discovered that formed a dimer with AHR in the nucleus, which was named the AHR nuclear receptor translocator (ARNT) (17). Finally, it was confirmed that the formation of the TCDD-AHR-ARNT complex was indispensable for the induction of AHH activity (18). In 1986, a nucleotide sequence, 5'-TNGCGTG-3', to which the TCDD-AHR-ARNT complex bound to induce the AHH activity, was identified and named dioxin response element (19). Subsequently, in Japan, studies were conducted using other xenobiotic compounds. These studies found that the xenobiotic-AHR-ARNT complex bound to the same sequence reported before, which was then renamed xenobiotic response elements (XRE); today it is also known as Ah response elements, a term used less often due to its similarity to the antioxidant response elements (AREs) (20,21). From that moment forward, the expression of CYP1A1 in response to natural compounds, drugs and other xenobiotics in general, has been used as an indirect evaluation of the participation of AHR, and therefore xenobiotic metabolism. However, it was subsequently recognized that these XRE sequences were found in a large number of gene promoters, and not only in CYP1A1. Nowadays, it is known that the function of AHR extends far beyond xenobiotic metabolism; it actually functions as a master regulator to control several biological processes, including cell proliferation, adhesion, differentiation and death, potentially among others not yet known (22).

\section{A glance at $A H R$ molecular features}

In 1994, the human $A H R$ promoter was cloned, and its main characteristics were described. First, this promoter was not found to contain a TATA box; instead, several binding motifs were identified, including multiple GC boxes, which act as binding sites for the transcription factor specificity protein 1 (Sp1). The $A H R$ promoter also possesses binding motifs for the transcription factor cAMP response elements and E-box, the last E-box is recognized by c-Myc (23). Furthermore, it has been described that distal-less 3, a homeobox transcription factor of importance during development in vertebrates, also binds to a portion of the $A H R$ promoter and enhances the transcription factor activity at the XRE sites (24). In addition, AHR possesses binding sites for signal transducer and activator of transcription 6 (STAT6), which belongs to the family of the transcription factors associated with the activity of cytokines such as interleukin (IL)-4 and
IL-13, and growth factors such as transforming growth factor- $\beta$ (TGF- $\beta$ ) (25). The $A H R$ promoter also possesses motifs to bind T-cell factor/lymphoid enhancer-binding factor (TCF/LEF), factors that are involved in the Wnt pathway by interacting with $\beta$-catenin (26). Finally, the $A H R$ promoter was also found to have 11 cis nuclear receptor binding sites, which include progesterone, androgen, glucocorticoid, proliferation-activated peroxisome, farsenoid $\mathrm{X}$ and the vitamin $\mathrm{D}$ receptors. The existence of a complete list of the AHR promoter characteristics enabled the understanding of the dual activity of AHR, with the constitutive one being associated with embryogenesis and fetal development when the receptor activity is particularly critical, and the second with specific tissue expression (27).

All these characteristics are conserved among the human and murine $A H R$ sequences, with the main difference between them being the mRNA length, which is longer in humans $(\sim 6.6 \mathrm{~kb})$ than in mice $(5.0-5.4 \mathrm{~kb})$. The open reading frame has 11 exons, organized to form a mature mRNA, with 28 domains in humans and 26 in mice (28). Focusing on the AHR domains, this receptor is a member of the basic Helix-Loop-Helix (bHLH) superfamily of transcriptional regulators. The members of this family are involved in critical developmental processes, including sex determination and the development of the nervous system and muscles. Like other members of this superfamily of proteins, it contains a binding region to DNA at the amino-terminal end and an additional Per-Arnt-Sim (PAS) domain at the carboxy-terminal $(29,30)$. The region of the basic residues is important for the interaction of AHR with the cis sequence of the XRE, while the bHLH motif is important for the heterodimerization between AHR and ARNT $(31,32)$.

\section{AHR-associated proteins}

AHR research was initially based only on its exposure to or interaction with TCDD, but the molecular structure of the AHR protein was unknown. In the cytosolic fraction, AHR exhibited a higher sedimentation value, which upon the addition of TCDD, was found to be decreased and located instead in the nuclear fraction (33). This finding revealed the existence of two different forms of the receptor, depending on cellular localization. It was shown electrophoretically in subsequent studies that this weight difference was due to the fact that the cytoplasm receptor was found in a protein complex that included 2 isoforms of mouse heat shock protein of $90 \mathrm{kDa}$ (Hsp90) and an X-associated protein 2, also known as AHR-interacting protein (AIP) or AHR-associated protein 9 (ARA9) (34-36). The proteins in this complex are important for the function of the AHR. The interaction between Hsp90 and AHR occurs in the PAS-B motif; this allows ligand binding to the receptor. In addition, AIP allows for protein-protein interaction (37). Once in the nucleus, the AHR protein undergoes degradation by the $26 \mathrm{~S}$ proteasome $(38,39)$ (Fig. 1), an important site for the degradation of other transcription factors, including TGF- $\beta$ (40) and myoblast determination protein 1 (41).

\section{Canonical AhR pathway}

To further understand the activation of the AhR canonical pathway (Fig. 1), a strong focus must be placed on the detoxification mechanism. This pathway begins in the cytoplasm 


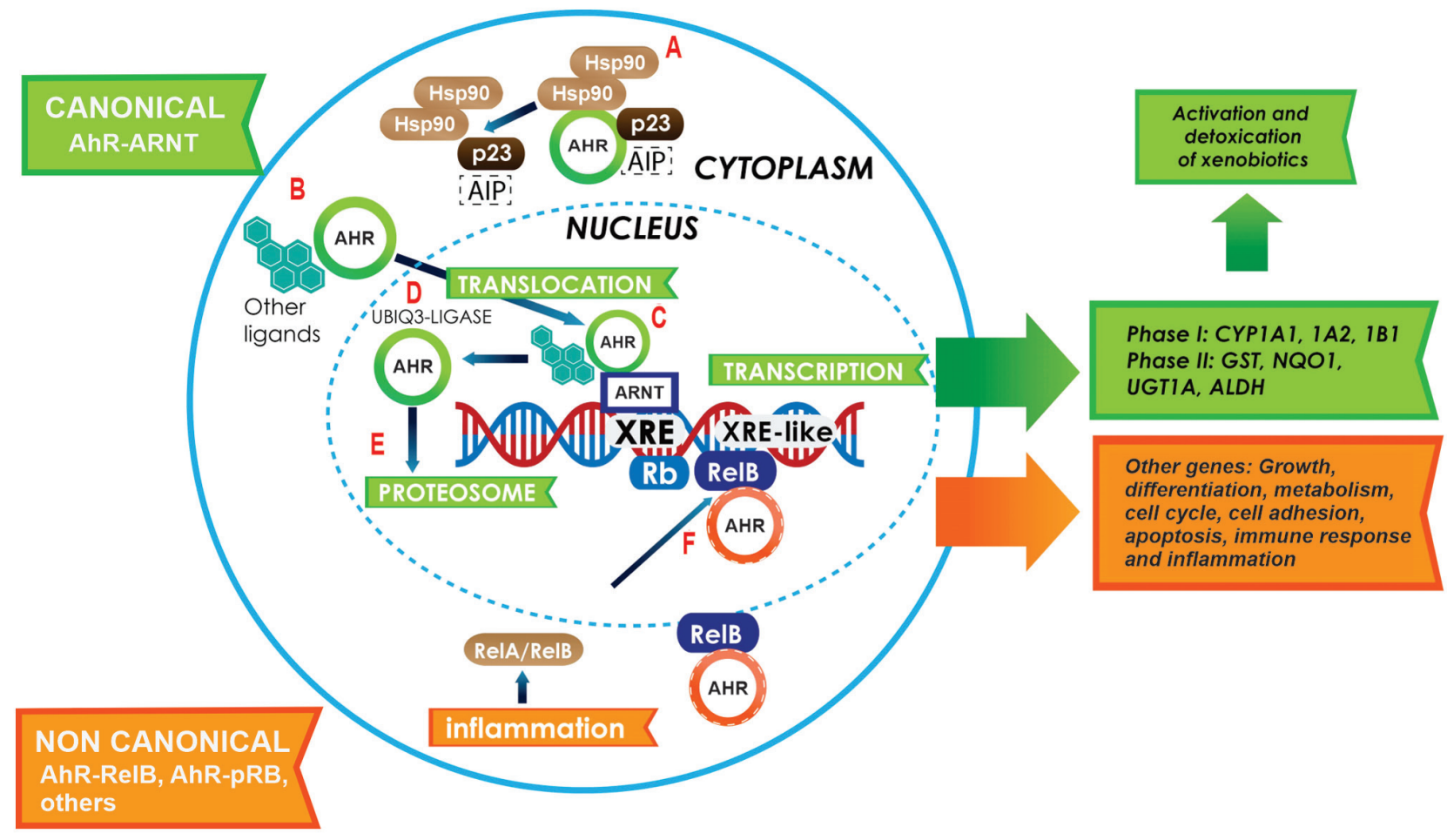

Figure 1. Canonical activation of the AhR pathway. In the cytoplasm, AHR resides in a molecular complex, to give it stability (A); this complex is formed with two Hsp90 proteins, AIP and p23. Following ligand binding, AHR dissociates from the complex and translocates to the nucleus (B). Inside the nucleus, AHR dimerizes with ARNT (green arrows) to form a heterodimer that binds to the XRE sites on the gene promoters involved in xenobiotic metabolism (C). Following the activation of response genes, AHR becomes the target of the ubiquitin 3-ligase (D) and undergoes degradation by the $26 \mathrm{~S}$ proteasome in the nucleus (E). The activation of the non-canonical pathway (orange arrows) is performed through the binding of AHR to other proteins, such as pRB, RelA or RelB. In this case, AHR and RelB together bind to other genes with an XRE cis site in their promoter, and activate several genes that participate in growth, differentiation, metabolism, the cell cycle, cell adhesion, apoptosis, immune response and inflammation (F). AHR, aryl hydrocarbon receptor; Hsp90, heat shock protein 90; AIP, AHR-interacting protein; ARNT, AHR nuclear receptor translocator; XRE, xenobiotic response elements; pRB, retinoblastoma.

with the binding of a ligand to AHR, which leads not only to a conformational change in AHR that exposes a nuclear localization signal (NLS), but also to the dissociation of Hsp90 from the complex, which enables the nuclear translocation promoted by the action of importins (42). Once in the nucleus, AHR dimerizes with its partner protein, ARNT, which is also a member of the bHLH family. The dimerization of AHR and ARNT is performed through the HLH domains of both proteins $(43,44)$, and a conformational change in the PAS A region helps stabilize this union (45). In addition, the phosphorylation of two regions in the carboxy-terminal of AHR via the protein kinase $\mathrm{C}$ is an important step for DNA binding (46). Once the AHR/ARNT heterodimer is formed, it binds to promoter regions of target genes that contain the XRE consensus sequence 5'-TNGCGT G-3'; AHR binds to the T/NGC5'-half-site, while ARNT binds to the GTG3'-half-site. This sequence is present in several genes, such as cytochromes; CYP1A1 contains 8 sites, CYP1A2 contains 1 and CYP1B1 contains $3(47,48)$. There is also an exceptional case, the poly/ADP-ribose polymerase, which contains 16 XRE cis sequences (49). Due to the vast number of studies on gene expression though AHR activation, several genes with XREs sequences have now been reported (50). Some of these genes are involved in xenobiotic metabolism, including phase I genes such as CYP1A1, CYP1A2, CYP1B1, $C Y P 2 A 5$ and $C Y P 4 B 1$, and phase II genes such as aldehyde dehydrogenase 3 family member A1, glutathione-S-transferase (GST), NAD(P)H-quinone oxidoreductase-1 (NQO1), UDP glucuronosyltransferase 1A1 (UGTIAI) and UGT1A6. Other genes involved in cell cycle regulation include suppressors such as cyclin dependent kinase inhibitor 1A (CDKNI; also known as p21), CDKN4 (also known as p27), retinoblastoma tumor suppressor protein $(p R B)$ and Kruppel-like factor $6(K L F 6)$, and activators such as proto-oncogenes c-Jun and c-Myc. Other genes involved in other signaling pathways include insulin-like growth factor $(I G F)$ binding protein-1, apoptosis regulator Bcl-2-associated X, cathepsin D, zinc finger protein slug, nuclear factor $\kappa \mathrm{B}$ subunit 1 and vascular endothelial growth factor $\mathrm{A}(V E G F)$ (51-55).

The first two groups (xenobiotic metabolism genes), are the most studied in relation to AhR pathway activation. The action of the cytochromes generates modifications in the xenobiotic compounds that facilitate their degradation, thus reducing the ligand concentrations in the cells. Most of the evidence currently available has demonstrated that AHR can function as an exogenous ligand sensor, since it belongs to a group of proteins that are known to be environmental sensors, but several of its ligands are compounds that appeared only recently in the human ecosystem (the technosphere). It can therefore be assumed that the canonical AhR pathway might be a response to the presence of 'new' toxic compounds in the environment (56). In this context, it is important to recognize the two major functions of AHR: Xenobiotic metabolism (detoxification) and its physiological role (development). The high interest in studying this receptor is not only fueled by its 
'normal' function, but also its interaction with several other proteins.

\section{Direct interactions between $A H R$ and other proteins}

$p R B$. One of the proteins that directly interact with AHR is pRB. This interaction occurs in the absence of ARNT (57). Two binding sites for $\mathrm{pRB}$ could be identified at the AHR sequence. The AHR-pRB complex functions as a co-repressor that inhibits the progression of the cell cycle by displacing the histone acetyl transferase p300 from E2F-dependent promoters, consequently inhibiting the expression of S-phase-specific genes $(58,59)$. In addition, AhR activation induces the expression of the cell cycle suppressors p21 and p27; the association of these inhibitors with cyclin D1 or E inhibits phosphorylation of $\mathrm{pRB}$, and as a result, the cycle is blocked at the $\mathrm{G}_{1}$ phase $(60,61)$.

$N F-\kappa \beta . \mathrm{NF}-\kappa \beta$ is another example of a protein that interacts directly with AHR in the absence of ARNT. EitherNF- $\kappa \beta$ subunit (RelA or RelB) can be involved. Exposure to TCDD induces the expression of IL-8 through a direct interaction between AHR and RelB, as this complex binds to a sequence very similar to XRE (5'-GGGTGCAT-3') on the IL-8 promoter (62). However, TCDD is also responsible for the interaction between AHR and RelA (63); this complex induces the expression of IL-1 $\beta$, tumor necrosis factor- $\alpha$, IL-6 (64) and proto-oncogene c-Myc (65).

Nuclear factor-erythroid 2-related factor 2 (NRF2). The interaction between AHR and NRF2 has been widely studied in recent times; however, for several years, these two pathways were thought to be entirely separate. This was due to NRF2 being a transcription factor that regulates genes containing AREs in their promoters. Several phase II genes of xenobiotic metabolism, including NQO1, UGT1A1, UGT1A6 and GST, have ARE sequences. Therefore, at first glance, exposure to TCDD appears to activate detoxification via the AhR canonical pathway, with no involvement of NRF2. The existence of a bidirectional cross-talk at the genetic level between AHR and NRF2 has now been well established. The NRF2 promoter has $\geq 1 \mathrm{XRE}$ sequence and the $A H R$ promoter has several AREs $(66,67)$. Since NRF2 is a master regulator of antioxidant responses, the metabolites generated by the xenobiotic metabolism yield the NRF2 activation to improve the detoxification efficiency.

Estradiol receptors (ERs). Evidence has revealed the antiestrogenic action of TCDD-type ligands. The first indication of this action is the modification activity of CYP1A1 and CYP1B1 on $17 \beta$-estradiol, and the production of a hormonal ligand with no estrogenic activity (68). Another indication is the binding of the AHR/ARNT heterodimer to the cis-inhibiting regions of the target response genes to the ER (69). Finally, the other molecular event that can explain the anti-estrogenic activity of AhR activation is the function of AHR as an E3 ubiquitin ligase towards the ERs that induces their degradation in the nucleus through the proteasome pathway (70).

\section{Non-canonical AhR pathway}

With great developments in microarray analysis during the last few decades, new horizons have been opened up in the field of
AhR research. Upon analyzing the cis regions of promoters and using chromatin immunoprecipitation, it was discovered that certain genes that were regulated by AHR have different sequences from those of the classical XREs; these sequences are known as non-consensus XRE (NC-XRE) (71,72). One example of these genes is the plasminogen-1 activator inhibitor (PAI-1) (73). Certain studies have shown that treatment with TCDD suppresses hepatic regeneration, as PAI-1 inhibits the urokinase-type plasminogen activator that is needed to activate the hepatic growth factor (74). A common characteristic among these non-consensus promotors is that they contain a repeated tetranucleotide motif (5'-GGGA-3'); in these cases, the interaction with ARNT is not necessary (75). With regards to PAI-1, it is now known that the suppression of hepatic regeneration is an arrest of cell proliferation caused by the inhibition of CDK2 activity (76). This blockade depends on the expression of kinase-dependent cyclin inhibitors such as p21 and p27, which negatively regulate cell cycle progression by controlling CDK activity. This regulation can take place due to the fact that the $\mathrm{p} 21$ promoter contains NC-XRE cis regions $(61,77)$. Recent evidence has suggested that KLF6 can form a heterodimer with AHR (78), which is able to bind to NC-XRE cis regions, where several of these family factors can interact. In fact, KLF4 and KLF6 can also regulate the expression of CYP1A1 in this manner. Structurally, this interaction takes place in the carboxy-terminal of AHR (where the bHLH and PAS-A domains are found), which must bind to the amino terminal of KLF6 (79). This factor also regulates numerous cellular processes, including proliferation, differentiation and apoptosis (80). Alterations in the expression of KLF6 are associated with various types of cancer, including astrocytomas and gliomas (81). In addition, KLF6 can increase the expression of $\mathrm{p} 21$, affecting cell cycle progression (82), as well as the expression of E-cadherin genes, TGF- $\beta 1$ and IGF1 receptor (83).

\section{Potential therapeutic applications of the crosstalk between AhR pathways and central nervous system (CNS) tumors}

Much of the knowledge regarding tumor growth is based on stem cell biology and developmental programs, since several signals are shared among these pathways. The new directed molecular therapies are designed to inhibit different tumor signaling pathways (84). For example, relevant growth factor pathways are known to be involved in malignant glioma, including platelet-derived growth factor, epidermal growth factor, VEGF, hepatocyte growth factor (HGF) and IGF (85). The physiological effects of AhR activation have been suggested to play an important role in the modulation of the immune system and carcinogenesis. AHR can therefore regulate inflammatory response and cell-cycle progression $(86,87)$. AHR is expressed at high levels and is chronically active in leukemia and lymphoma (88-90), as well as in solid tumors such as glioblastoma, ovarian cancer $(91,92)$, lung cancer $(93,94)$, liver cancer (95), and head and neck carcinomas (96). The role of AhR in cancer is very complex and depends on tumor type. Evidence has shown that the activated AhR pathway is associated with tumor growth promotion, but there is also evidence of its tumor-suppressive activity. Some of the potential 


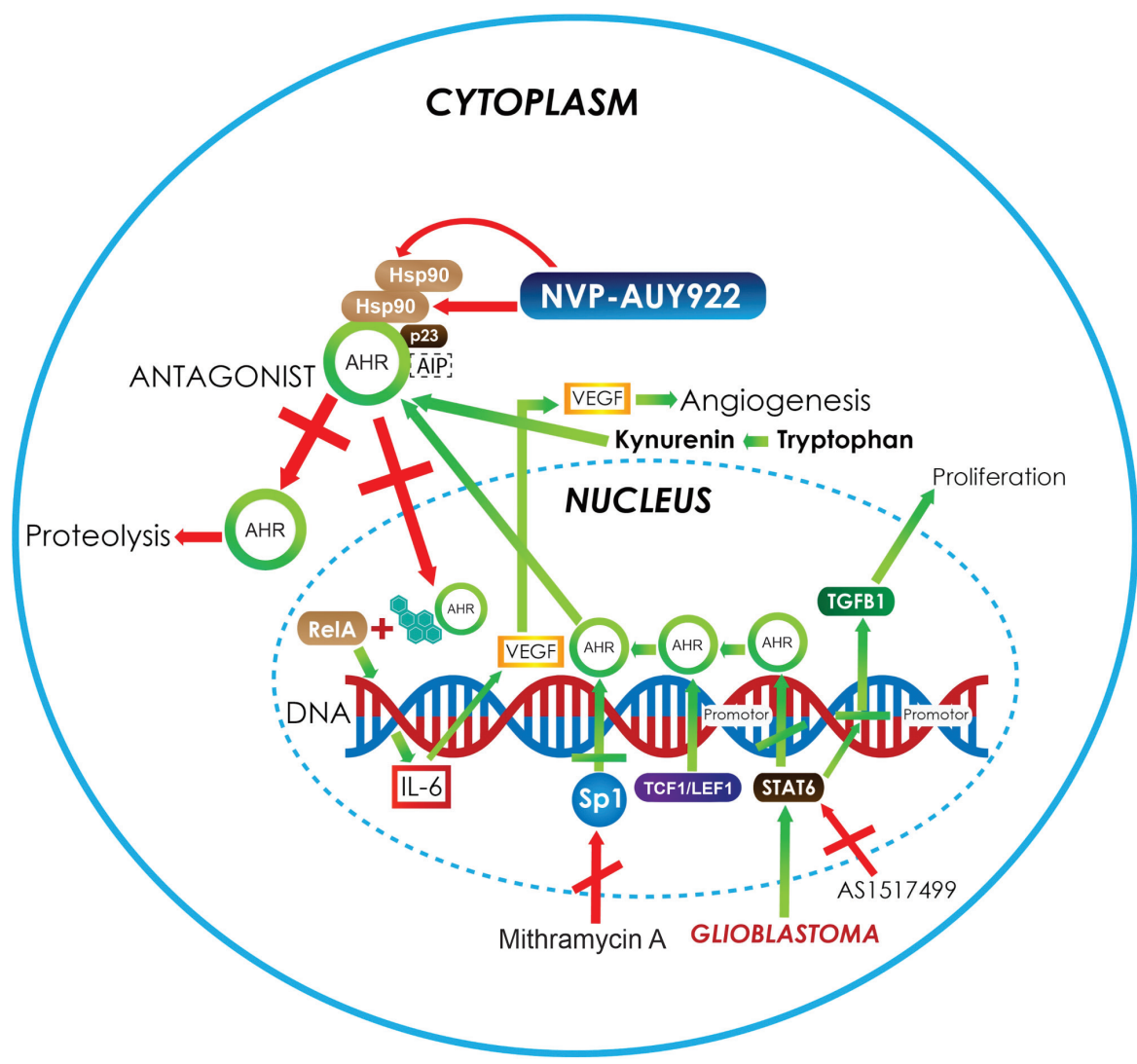

Figure 2. In astrocytoma and glioblastoma, the activation of the AhR pathway increases the expression of several genes, such as VEGF and TGF- $\beta 1$ (green arrows) that are involved in angiogenesis and proliferation processes. In addition, the overexpression of Sp1 activates the transcription of $A H R$, increasing its protein levels. Moreover, there are AHR ligands, such as tryptophan metabolites, produced by the kynurenine pathway in central nervous system tumors such as astrocytoma (green arrows), which also bind and activate the AhR pathway. The strategies used to control the growth of neoplastic cells in astrocytoma and glioblastoma (red arrows) mainly involve the use of AHR antagonist. Another target for therapy is the use of complex-associated protein inhibitors to induce the instability of the receptor. An example of this is NVP-AUY922, which inhibits Hsp90 and induces AHR degradation. Another example is the use of inhibitors such as mithramycin A and AS1517499, which control the autoinduction of AHR protein expression and stop reactive responses. AHR, aryl hydrocarbon receptor; VEGF, vascular endothelial growth factor A; TGF- $\beta 1$, transforming growth factor- $\beta$; Hsp90, heat shock protein 90 ; Sp1, specificity protein 1; TCF1/LEF1, T-cell factor/lymphoid enhancer-binding factor; AIP, AHR-interacting protein; IL, interleukin.

therapeutic applications of AHR activity in the most studied types of CNS tumors (astrocytomas, medulloblastomas and neuroblastomas) are explored in the next sections.

Astrocytomas. Also known as gliomas, astrocytomas are a large group of different types of pediatric and adult tumors that develop from glial cells; specifically, astrocytomas originate from astrocytes, which are essential for the structure and support of neurons. Traditionally, these tumor types were classified by the World Health Organization (WHO) based only on histopathological analysis; in fact, based on the presence or absence of marked mitotic activity, necrosis and microvascular proliferation, tumors were also classified by a WHO malignancy grading system: Grade II, low grade; grade III anaplastic; grade IV, glioblastoma. Nowadays, these tumor types have been reclassified based on their histological and molecular features $(97,98)$.

AhR research has provided evidence on how this pathway can be targeted for therapeutic applications. Regarding astrocytomas in particular, it has been reported that IL-6 induces the transcriptional activation of VEGF, which, in turn, participates in the induction of angiogenesis in this type of tumor. As aforementioned, AHR can form a heterodimer with RelA to trigger the activation of IL-6, which, finally, fosters de novo angiogenesis-dependent tumor growth (99). In the context of astrocytic tumors, for instance, it is well known that glioblastomas are characterized by high expression of STAT6, a trans-acting factor that can alter the expression of $A H R$ and other cytokines, such as IL-6 (Fig. 2). It is also known that AHR regulates its own expression, which may contribute not only to an increase in the expression of angiogenic factors, but also to the production of other cytokines, such as TGF- $\beta$, which also promotes tumor growth (100). In fact, it is also well known that the high expression of STAT6 in glioblastoma patients is correlated with lower survival rates and has been identified as a potential prognostic marker (101).

In addition to study of the canonical AhR pathway and its activation by PAH-type ligands, research is underway to establish an association between the activation produced by the exposure to xenobiotic compounds and the development of CNS tumors. The current hypothesis is that the genetic variants of the receptor can modify and/or increase the risk of glioma development following exposure to $\mathrm{PAH}$, and thus establish the gene-environment interaction that leads to the development of glioma (102). The first direct epidemiological study to provide this type of evidence was that of $\mathrm{Gu}$ et al (102), which consisted of a case-control study of 384 glioma cases and 384 cancer-free controls in a Chinese population. It was 
proposed that two polymorphisms of the $A h R$ may increase susceptibility to glioma development, and hence to the formation PAH-DNA adducts, thus consequently increasing the risk of carcinogenesis in glial cells. This was evidenced by the staining of DNA-PAH adducts, which revealed an association between staining intensity and glioma grade (102). A study showed that cigarette smoking had no effect on glioma development, since smoking is not the principal factor in PAH-DNA adduct formation; in fact, exposure to air pollutants or the smoke generated by the burning of organic material has greater effects on glioma formation than smoking (103).

As aforementioned, changes in the expression of the xenobiotic metabolizing genes, such as cytochromes $C Y P 1 A 1$ and $C Y P 1 A 2$, are produced by AhR activation. However, exposure to an AHR agonist, 3,3',4,4',5-pentachlorobiphenyl (penta-CB), a coplanar polychlorinated biphenyl, unexpectedly does not cause a significant transcriptional activation of CYP1A1 in C6 glioma cell lines (104). In addition, when comparing 4HIIB hepatoma and C6 glioma cell lines, the overexpression of genes that participate in tumor promotion and progression, protein processing, programmed cell death and/or metastasis was identified in glioma cells (104). Moreover, in the $\mathrm{C} 6$ glioma cell line, significant overexpression of galectin-1 was observed, which is known to permit protein-protein interactions and may influence the progression of the cell cycle and other cellular functions (104). These data confirmed that certain AHR ligands, such as penta-CB, causes tissue-selective chromatin remodeling via histone deacetylase inhibitors; as a result AhR induces the expression of specialized genes associated with carcinogenesis in glioma cells (104). On the other hand, it is well known that AhR and TGF- $\beta$ signaling are mutually regulated in a cell-specific manner (105). Furthermore TGF- $\beta$ is a crucial factor in the malignant phenotype of glioblastomas and is also a downstream target of AhR signaling (105). In addition AHR can activate the expression of latent TGF- $\beta$ binding protein 1 (LTBP-1), a protein characterized as crucial in the TGF- $\beta$ activation in gliomas (Fig. 2), such that a strengthened signal regulated by AHR is doubly established in glioblastoma cells (105). Consequently, the LTBP-1/TGF- $\beta$ pathway in glioma cells promotes proliferation, clonogenicity and invasiveness, and more importantly, the use of an AhR antagonists, such as CH-223191 or AHR gene silencing blocks these effects (105). Therefore, AHR antagonists may be useful for managing and controlling glioma growth.

In addition, astrocytomas have been associated with the high expression of Wnt signaling transcription factors such as TCF-1 and LEF-1 (Fig. 2). It has also been demonstrated that LEF-1 is capable of distinguishing grade II and III astrocytomas from glioblastomas, and it may therefore be considered an important marker of progression (106). Considering this, along with the fact that the $A H R$ promoter has TCF/LEF binding sites, it stands to reason that an increase in the expression of AHR may also participate in astrocytoma progression (Fig. 2). In all cases cited herein, the application of AHR antagonists could have therapeutic effects; such treatments could have the ability to reduce the synergistic effects of AhR among other pathways and, perhaps, be able to improve responses to surgery or chemotherapy. It has been shown, for example, that the use of Hsp90 inhibitors, such as NVP-AUY922, increases the cytotoxic effect of ionizing radiation in different cancer cell lines, including glioblastoma cell lines (107). Notably, two Hsp90 proteins are part of the AHR complex and play an important role in the stabilization and structure of the active receptor. The use of this inhibitor would not allow Hsp90 to bind to AHR in the correct way, thus leaving the receptor labile in the cytoplasm, where it is a target for degradation (Fig. 2).

Otherwise, in the context of tans factors such as Sp1, which is known to be increased in glioblastoma cell lines, these in fact bind to GC-rich cis regions in the AHR promoter, therefore increasing receptor transcription and protein level. Mithramycin A is a chemotherapeutic agent used in the treatment of solid tumors (Fig. 2); it has been shown to be an inhibitor of Sp1 and to reduce the secretion of metalloproteinases in astrocytoma cell lines, thus reducing the production of VEGF and, as a result, decreasing glioma cell migration (108). This mechanism may be a consequence of the low expression of $A H R$, which, in turn, reduces the levels of IL-6, finally leading to a decrease in VEGF expression (99). Another way to control the inductive effect of AhR is through the use of STAT6 inhibitors such as AS1517499, which, synergistically with AHR antagonists, reduce the production of the receptor, thus controlling the effects of angiogenesis and cell proliferation (Fig. 2) (109). Functional, genomic and molecular studies have confirmed that the endogenous expression of AHR protects against glioblastoma cell invasion and growth. Using CRISPR/Cas9 in the U87 cell line and patient-derived cells to stably knockout $A H R$ expression or downregulate expression using RNA interference against AHR, resulted in an increase in cell invasion in Boyden chamber and 3D tumor spheroid assays, and also enhanced cell migration in scratch assays. These results confirmed that AHR exhibits a tumor-suppressive role in glioblastoma cells and functions as an inhibitor of glioblastoma cell invasion (110). These findings are of extreme importance, since they revealed the endogenous function of AHR when used as a therapeutic target. Notably, ligands are only used to modify the expression patterns and not to completely block its activity.

Medulloblastomas. Medulloblastomas are primary cerebellar tumors and the most common type of malignant brain tumor in children with a global incidence of 0.49 per 100,000 , accounting for $\sim 20 \%$ of all pediatric tumors of the CNS and $64.9 \%$ of all embryonal tumors in children and adolescents (age 0-19 years) in 2008-2016 (111-113). The medulloblastomas cell origin remains elusive, but is thought that they originate from abnormally proliferating cerebellar granule neuron precursors (GNPs) and/or multipotent neural stem cells (NSCs) $(114,115)$. These types of tumor occur exclusively in the posterior fossa, and their typical treatment consists of a combination of chemotherapy and surgical resection (116,117). Medulloblastoma survivors suffer sequelae, including cognitive deficits, and problems with neuroendocrine functions and fertility $(118,119)$. Different treatment options are therefore required. Recent insights into the biology of medulloblastoma have revealed molecular features that improve its categorization into molecular subgroups: Wnt, sonic hedgehog (Shh), group 3 and group 4 (both classified as non-Wnt/Shh) (120). However, this classification has not yet been used for risk stratification in clinical trials. 


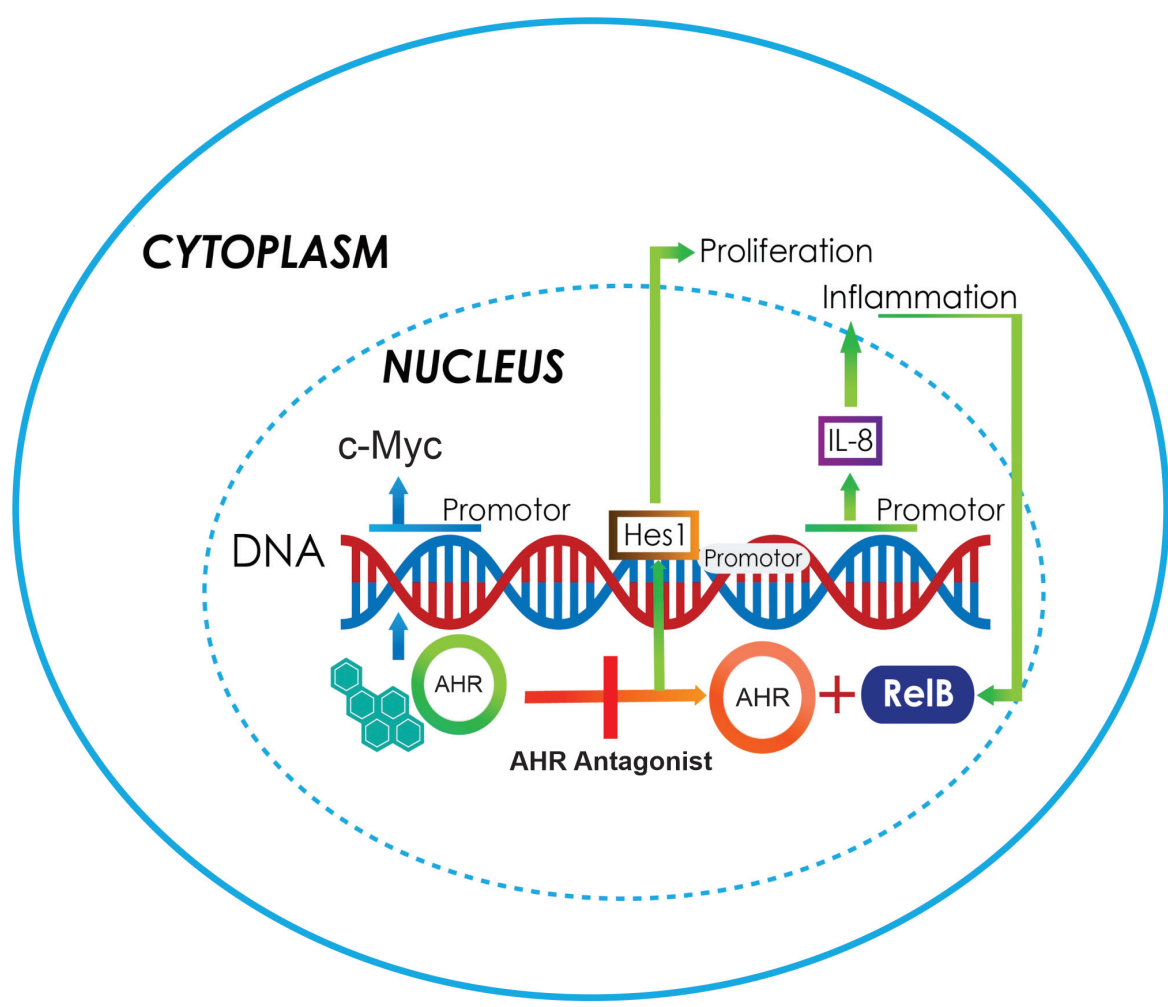

Figure 3. Increased expression of c-Myc is the main characteristic of medulloblastomas, and could be a result of the overexpression of $A H R$, a transcriptional activator (blue arrows). This, in turn, induces an increase in Hes1 gene expression and causes proliferation (green arrows). Another aspect is the activation of several genes due to the action of AHR/RelB, including those responsible for IL- 6 secretion and inflammation. Data have suggested that the best therapeutic strategy is to antagonize the AhR pathway (orange arrow). AHR, aryl hydrocarbon receptor; IL, interleukin.

GNPs express high levels of $A H R$ in the external germinal layer of the developing cerebellum, with the abnormal activation or deletion of $A H R$ leading to the dysregulation of the GNP cell cycle and maturation. A stable $A H R$-knockdown in a DAOY medulloblastoma cell line revealed an impaired $G_{1}$ to $\mathrm{S}$ transition, decreased DNA synthesis and reduced proliferation. These effects are also correlated with the decreased levels of the proliferative gene Hes1 and increased levels of the cell cycle inhibitor p27. All the alterations were reversed following the supplementation of human AHR. These results demonstrated that the abnormal activation or suppression of AHR could dysregulate the GNP cell cycle and promote the proliferation of medulloblastoma cells (121). c-Myc is known to be significantly involved in the generation of the malignant properties of medulloblastoma cells. This carcinogenic process also has a synergistic action with HGF expression, which contributes to the process of becoming malignant. Despite the fact that $A H R$ contains in its promoter sequence a cis E-box, it is highly plausible that the overexpression of c-Myc increases the expression of $A H R$, exerting effects that may favor cell growth and proliferation (122). In these cases, the use of AHR antagonists will be useful for controlling cell proliferation (Fig. 3).

With regards to Shh medulloblastoma in particular, some cells are cancer-propagating cells (CPCs) that express SOX2; this signal is essential for tumor stem cell maintenance. These cells do not lose their proliferation capacity following anti-mitotic chemotherapy and are eventually responsible for tumor relapse. The AHR function has recently been linked to CPCs and tumor stem cell maintenance; in fact, AHR was shown to regulate the balance between quiescence and proliferation. This was demonstrated in AHR-deficient animals, which exhibited decreased quiescence and increased tumor stem cell proliferation (123). This finding suggested an important tumor-suppressive role of AHR in mouse Shh medulloblastoma.

Neuroblastomas. Neuroblastoma is a type of cancer that occurs in young children and starts early during embryonic or fetal development, the median age at diagnosis is between 16 and 24 months $(124,125)$. Neuroblastoma is the most frequent type of solid extracranial tumor in children which represented 3-8\% of childhood malignancies worldwide in 2001-2010 (126,127). This tumor type is derived from early nerve cells called neuroblasts, most of which develop in the adrenal glands; however, some of them can expand to other areas, such as the thorax, spinal column, medulla or abdomen $(128,129)$. In vitro studies have revealed that the overexpression of $A H R$ induces cell differentiation, and that the expression of the receptor is highly correlated with the histological grade of differentiation of the tumors $(130,131)$. AHR was recently reported to be expressed in the cerebellar GNPs during the early postnatal period, where it regulates the growth and differentiation of granule neuroblasts (132). AHR-deficient mice have been shown to display a diminished neuronal differentiation in the dentate gyrus, with the knockout of AHR causing oculomotor and optic nerve deficits in a mouse model (132). This suggested that the overexpression of AHR promotes neural differentiation in neuroblastoma cells. Antecedents in breast cancer cells reveal that c-Myc, an oncogene whose promoter contains 6 XREs, is 
repressed by the constitutive expression of AHR (133). This interaction may occur due to the action of the E2F1 protein. It is not yet clear which protein establishes a direct interaction with AHR on the promoter of the c-Myc gene in neuroblastoma cells to produce this repression. It is, however, plausible that it forms a co-repressor complex upon interacting with E2F1, similar to the effect described in MCF-7 breast cancer cells, where AHR interacted with the $\mathrm{pRB}$ protein (134). A recent study has shown that AHR plays an important role in neurogenesis and differentiation, as aforementioned, since its receptor contains cis binding sites for trans factors expressed in the early stages of development and differentiation, such as brain-specific homeobox/POU domain protein 3B (135).

Using an SK-N-SH NB cell line treated with catabolites of the corticosterone tetrahydrocorticosterone (THB), $5 \alpha-\mathrm{THB}$ or $5 \beta$-THB, for 3 days, the neuronal differentiation markers, growth-associated protein 43 neurofilament heavy chain and neuron-specific enolase were found to be upregulated. The mRNA expression of SOX10 and MBP, which are early markers of myelinating cells, was also found to be upregulated in the treated cells. These results showed that $5 \alpha-$ and $5 \beta-$ THB promote the expression of neuronal and myelinating glial differentiation markers in SK-N-SH NB cells, revealing a potential therapeutic use for $5 \alpha$ - and $5 \beta$-THB in neuroblastoma (135). However, the presence of a ligand such as TCDD interrupts neurogenesis. Therefore, in neuroblastoma tumors, AHR acts as a tumor-suppressive gene and promotes cell differentiation. A study has suggested that the parents of children suffering from neuroblastoma were probably exposed to xenobiotic-type AHR ligands during the prenatal period, and that this suppression of neuronal development was the consequence of inhibiting the normal function of AHR (131). This could be a new method of establishing the association between environmental contaminants and the genesis of tumors such as neuroblastoma (131).

Kynurenine $(K Y N)$ pathway. AhR pathway activation by environmental xenobiotic compounds has already been discussed in the present review; however, certain endogenous ligands could also activate this pathway. The tryptophan catabolite kynurenine (KYN) was the first endogenous ligand described for AHR. KYN is produced by the KYN pathway among other neuroactive metabolites, including KYN acid, 3-hydroxykynurenine, anthranilic acid, 3-hydroxyanthranilic acid, picolinic acid (PIC), N-methyl-D-aspartate agonist and quinolinic acid (QUIN), from which $\mathrm{NAD}^{+}$is synthetized. In the CNS, the kynurenine pathway metabolizes $\sim 95 \%$ of tryptophan (136). Nowadays, it is well known that, in CNS tumors, the AhR-kynurenine pathway is active and associated with malignant progression and poor survival.

Neuroblastoma cells overexpress 2,3-dioxygenase enzyme and suppress $\alpha$-amino- $\beta$-carboxymuconate- $\varepsilon$-semialdehyde decarboxylase (137). In addition, these cells produce more QUIN, a neurotoxin, and less PIC. PIC is a neuroprotective metabolite with antiproliferative effects (138) that produces the characteristic neurotoxicity of CNS tumors (139); this neurotoxicity is comparable to the necrotic effect observed in multiforme glioblastomas due to the release of glutamate, which is excessively neurotoxic and causes neuronal death (140). In addition, it is clear that the KYN produced by these tumors in gliomas acts as an immune suppressor, and promotes the survival and motility of tumor cells by activating the AhR pathway. Therefore, there is an association between tumor progression and low survival rates in patients with high AHR expression (141). The KYN-AhR pathway can be used as a target in therapeutic applications for CNS tumor growth control, as KYN is a proven ligand for AHR. The use of antagonists, including certain aromatic compounds such as flavones and polyphenols, could block the pathway activation and stop tumor growth $(142,143)$.

\section{Conclusions}

Based on the analysis of the molecular biology, biochemistry and physiology of the AhR and its pathway, the following conclusions can be reached: i) Certain transcription factor inhibitors could be used to increase the protein levels of AHR and, as a result, since AHR regulates several cell processes, it may be possible to achieve the important control of some cellular processes by inhibiting the activity of AhR pathway in malignant tumors of the CNS. ii) Compounds that can antagonize the canonical AhR pathway could also be used as treatment, such as the flavones. This field has not yet been fully explored, and future research should be conducted with the objective of progressively broadening targets and possibilities for the control of tumors, based on studies of the AhR pathway. iii) It is important to explore compounds that can inhibit the components of the cytoplasmic AHR complex, such as Hsp90 (for which one already exists, NVP-AUY922), AIP and $\mathrm{p} 23$. This reduces the stability of the receptor in the cytoplasm, which is rendered highly labile and can be degraded, indirectly inhibiting the activator effect of various cell processes. iv) Another matter that requires attention is the fact that not all the processes that AHR regulates are directed towards activating/increasing responses; some are directed towards inhibiting responses. One such process is the interaction between AHR and KLF6, which activates transcription and increases the protein expression of $\mathrm{p} 21$, thus blocking the cell cycle progression. For that reason, it is important to conduct analyses to confirm these processes and determine whether they involve activation or repression.

\section{Acknowledgements}

This review is a required part of the PhD Graduate Program in Biological Sciences of the National Autonomous University of Mexico. The authors would like to acknowledge scholarship CVU-508581 provided by the Consejo Nacional de Ciencia y Tecnología (CONACYT) and the support of the University and the Biological Sciences PhD program of the Universidad Nacional Autónoma de México.

\section{Funding}

The financial support to pay for the publication was obtained from the Dirección de Investigación of Hospital Infantil de México Federico Gómez (grant no. HIM-2019-029.SSA1574).

\section{Availability of data and materials}

Not applicable. 


\section{Authors' contributions}

MZO revised and corrected the text and figures and performed the review of the information. EAV performed the review of articles, prepared information and designed the figures. FAH reviewed information, wrote and revised the manuscript. MZO, EAV and FAH confirm the authenticity of all raw data. All the authors have made substantive intellectual contributions and meet the conditions of authorship. All authors have read and approved the manuscript.

\section{Ethics approval and consent to participate}

Not applicable.

\section{Patient consent for publication}

Not applicable.

\section{Competing interests}

The authors declare that they have no competing interests.

\section{References}

1. Schulz KH: Clinical \& experimental studies on the etiology of chloracne. Arch Clinical Exp Dematol 206: 589-596, 1957 (In German).

2. Kimmig J and Schulz KH: Occupational acne (so-called chloracne) due to chlorinated aromatic cyclic ethers. Dermatologica 115: 540-546, 1957 (In German).

3. Poland A and Glover E: 2,3,7,8-Tetrachlorodibenzo-p-dioxin: A potent inducer of-aminolevulinic acid synthetase. Science 179: 476-477, 1973

4. Richardson HL, Stier AR and Borsos-Nachtnebel E: Liver tumor inhibition and adrenal histologic responses in rats to which 3'-methyl-4-dimethylaminoazobenzene and 20-methylcholanthrene were simultaneously administrated. Cancer Res 12: 356-361, 1952.

5. Conney AH, Miller EC and Miller JA: Substrate-induced synthesis and other properties of benzpyrene hydroxylase in rat liver. J Biol Chem 228: 753-766, 1957

6. Nebert DW and Bausserman L: Genetic differences in the extent of aryl hydrocarbon hydroxylase induction in mouse fetal cell cultures. J Biol Chem 245: 6373-6382, 1970.

7. Nebert DW and Gelboin HV: The in vivo and in vitro induction of aryl hydrocarbon hydroxylase in mammalian cells of different species, tissues, strains, and developmental and hormonal states. Achr Biochem Biophys 134: 76-89, 1969.

8. Nebert DW, Negishi M, Lang MA, Hjelmeland LM and Eisen HJ: The Ah locus, a multigene family necessary for survival in a chemically adverse environment: Comparison with the immune system. Adv Genet 21: 1-51, 1982.

9. Nebert DW, Goujon FM and Gielen JE: Aryl hydrocarbon hydroxylase induction by polycyclic hydrocarbons: Simple autosomal dominant trait in the mouse. Nat New Biol 236 107-110, 1972

10. Nebert DW: The 1986 Bernard B. Brodie award lecture. The genetic regulation of drug-metabolizing enzymes. Drug Metab Dispos 16: 1-8, 1988.

11. Poland A and Glover E: Comparison of 2,3,7,8-tetrachlorodibenzo-p-dioxin, a potent inducer of aryl hydrocarbon hydroxylase, with 3-methylcholanthrene. Mol Pharmacol 10 : 349-359, 1974

12. Poland A, Glover E, Robinson JR and Nebert DW: Genetic expression of aryl hydrocarbon hydroxylase activity. Induction of monooxygenase activities and cytochrome P1-450 formation by 2,3,7,8-tetrachlorodibenzo-p-dioxin in mice genetically 'nonresponsive' to other aromatic hydrocarbons. J Biol Chem 249: 5599-5606, 1974.
13. Yueh MF, Huang YH, Hiller A, Chen S, Nguyen $\mathrm{N}$ and Tukey RH: Involvement of the xenobiotic response element (XRE) in Ah receptor-mediated induction of human UDPglucuronosyltransferase 1A1. J Biol Chem 278: 15002-15006, 2003.

14. Poland A, Glover E and Kende AS: Stereospecific, high affinity binding of 2,3,7,8-tetrachlorodibenzo-p-dioxin by hepatic cytosol. Evidence that the binding species is receptor for induction of aryl hydrocarbon hydroxylase. J Biol Chem 251: 4936-4946, 1976.

15. Gasiewicz TA and Henry E: History of research on the AhR. In: Pohjanvirta R (ed). The AH receptor in biology and toxicology. Hoboken, New Jersey, John Wiley \& Sons, pp3-32, 2012.

16. Gasiewicz TA and Bauman PA: Heterogeneity of the rat hepatic Ah receptor and evidence for transformation in vitro and in vivo. J Biol Chem 262: 2116-2120, 1987.

17. Reyes H, Reisz-Porszasz S and Hankinson O: Identification of the Ah receptor nuclear translocator proteins (Arnt) as a component of the DNA binding form of the Ah receptor. Science 256: 1193-1195, 1992.

18. Miller AG, Israel D and Whitlock JP Jr: Biochemical and genetic analysis of variant mouse hepatoma cells defective in the induction of benzo(a)pyrene-metabolizing enzyme activity. J Biol Chem 258: 3523-3527, 1983.

19. Jones PB, Durrin LK, Galeazzi DR and Whitlock JP Jr: Control of cytochrome P1-450 gene expression: Analysis of a dioxin-responsive enhancer system. Proc Nat Acad Sci USA 83: 2802-2806, 1986

20. Fujisawa-Sehara A, Yamane M and Fujii-Kuriyama Y: A DNA-binding factor specific for xenobiotic responsive elements of P-450c gene exists as a cryptic form in cytoplasm: Its possible translocation to nucleus. Proc Natl Acad Sci USA 85: 5859-5863, 1988.

21. Pohjanvirta R, Korkalainen M, Moffat ID, Boutros PC and Okey AB: Role of the AHR and its structure in TCDD toxicity. In: Pohjanvirta R (ed). The AH receptor in biology and toxicology. Hoboken, New Jersey, John Wiley \& Sons, pp179-196, 2012.

22. DeGroot D, He G, Fraccalvieri D, Bonati L, Pandini A and Denison MS: Ahr ligands: Promiscuity in binding and diversity in response. In: Pohjanvirta $\mathrm{R}$ (ed). The AH receptor in biology and toxicology. Hoboken, New Jersey, John Wiley \& Sons, pp63-79, 2011.

23. Eguchi H, Hayashi S, Watanabe J, Gotoh O and Kawajiri K: Molecular cloning of the human Ah receptor gene promoter. Biochem Biophys Res Comm 203: 615-622, 1994.

24. Shin JH, Haggadone MD and Sunwoo JB: Transcription factor Dlx3 induces aryl hydrocarbon receptor promoter activity. Biochem Biophys Rep 7: 353-360, 2016.

25. Tanaka G, Kanaji S, Hirano A, Arima K, Shinagawa A, Goda C, Yasunaga S, Ikizawa K, Yanagihara Y, Kubo M, et al: Induction and activation of the aryl hydrocarbon receptor by IL-4 in B cells. Int Immunol 17: 797-805, 2005.

26. Eastman Q and Grosschedl R: Regulation of LEF-1/TCF transcription factors by Wnt and other signals. Curr Opin Cell Biol 11: 233-240, 1999.

27. Harper PA, Riddick DS and Okey AB: Regulating the regulator: Factors that control levels and activity of the aryl hydrocarbon receptor. Biochem Pharmacol 72: 267-279, 2006.

28. Hahn ME: Aryl hydrocarbon receptors: Diversity and evolution. Chem Biol Interact 141: 131-160, 2002.

29. Burbach KM, Poland A and Bradfield CA: Cloning of the Ah-receptor cDNA reveals a distinctive ligand-activated transcription factor. Proc Natl Acad Sci USA 89: 8185-8189, 1992.

30. Ma Q: Overview of AHR functional domains and the classical AHR signaling pathway: Induction of drug metabolizing enzymes. In: The AH Receptor in Biology and Toxicology. Pohjanvirta R (ed). John Wiley \& Sons, Hoboken, New Jersey, pp35-45, 2012.

31. Ma Q, Whitlock JP Jr: A novel cytoplasmic protein that interacts with the Ah receptor, contains tetratricopeptide repeat motifs, and augments the transcriptional response to 2,3,7,8-tetrachlorodibenzo-p-dioxin. J Biol Chem 272: 8878-8884, 1997.

32. Ma Q, Dong L and Whitlock JP Jr: Transcriptional activation by the mouse Ah receptor. Interplay between multiple stimulatory and inhibitory functions. J Biol Chem 270: 12697-12703, 1995.

33. Murray IA and Perdew GH: Role of the chaperone proteins in ahr function. In: The AH Receptor in Biology and Toxicology. Pohjanvirta R (ed). John Wiley \& Sons, Hoboken, New Jersey, pp47-61, 2011. 
34. Chen HS and Perdew GH: Subunit composition of the heteromeric cytosolic aryl hydrocarbon receptor complex. J Biol Chem 269: 27554-27558, 1994.

35. Meyer BK, Pray-Grant MG, Vanden Heuvel JP and Perdew GH: Hepatitis B virus X-associated protein 2 is a subunit of the unliganded aryl hydrocarbon receptor core complex and exhibits transcriptional enhancer activity. Mol Cel Biol 18: 978-988, 1998

36. Carver LA, LaPres JJ, Jain S, Dunham EE and Bradfield CA: Characterization of the Ah receptor-associated protein, ARA9. J Biol Chem 273: 33580-33587, 1998.

37. Schreiber SL: Chemistry and biology of the immunophilins and their immunosuppressive ligands. Science 251: 283-287, 1991.

38. Ma Q and Baldwin KT: 2,3,7,8-tetrachlorodibenzo-p-dioxininduced degradation of aryl hydrocarbon receptor (AhR) by the ubiquitin-proteasome pathway. Role of the transcription activation and DNA binding of AhR. J Biol Chem 275: 8432-8438, 2000.

39. Roberts BJ and Whitelaw ML: Degradation of the basic helix-loop-helix/Per-ARNT-Sim homology domain dioxin receptor via the ubiquitin/proteasome pathway. J Biol Chem 274: 36351-36356, 1999.

40. Lo RS and Massagué J: Ubiquitin-dependent degradation of TGF-beta-activated Smad2. Nat Cell Biol 1: 472-478 1999.

41. Floyd ZE, Trausch-Azar JS, Reinstein E, Ciechanover A and Schwartz AL: The nuclear ubiquitin-proteasome system degrades MyoD. J Biol Chem 276: 22468-22475, 2001

42. Ikuta T, Eguchi H, Tachibana T, Yoneda Y and Kawajiri K Nuclear localization and export signals of the human aryl hydrocarbon receptor. J Biol Chem 273: 2895-2904, 1998.

43. Fukunaga BN, Probst MR, Reisz-Porszasz S and Hankinson O Identification of functional domains of the aryl hydrocarbon receptor. J Biol Chem 270: 29270-29278, 1995.

44. Reisz-Porszasz S, Probst MR, Fukunaga BN and Hankinson O Identification of functional domains of the aryl hydrocarbon receptor nuclear translocator protein (ARNT). Mol Cell Biol 14: 6075-6086, 1994.

45. Soshilov A and Denison MS: Role of the Per/Arnt/Sim domains in ligand-dependent transformation of the aryl hydrocarbon receptor. J Biol Chem 283: 32995-33005, 2008.

46. Mahon MJ and Gasiewicz TA: Ah receptor phosphorylation: Localization of phosphorylation sites to the C-terminal half of the protein. Arch Biochem Biophys 318: 166-174, 1995.

47. Swanson H: Dioxin response elements and regulation of gene transcription. In: The AH Receptor in Biology and Toxicology. Pohjanvirta R (ed). John Wiley \& Sons, Hoboken, New Jersey, pp81-91, 2012

48. Bacsi S, Reisz-Porszasz S and Hankinson O: Orientation of the heterodimeric aryl hydrocarbon (dioxin) receptor complex on its asymmetric DNA recognition sequence. Mol Pharmacol 47: 432-438, 1995

49. Ma Q: Induction and superinduction of 2,3,7,8-tetrachlorodibenzo-rho-dioxin-inducible poly(ADP-ribose) polymerase: Role of the aryl hydrocarbon receptor/aryl hydrocarbon receptor nuclear translocator transcription activation domains and a labile transcription repressor. Arch Biochem Biophys 404: 309-316, 2002.

50. Gasiewicz TA, Henry EC and Collins LL: Expression and activity of aryl hydrocarbon receptors in development and cancer. Crit Review Eukaryotic Gene Exp 18: 279-321, 2008.

51. Barouki R, Coumoul X and Fernandez-Salguero PM: The aryl hydrocarbon receptor, more than a xenobiotic-interacting protein, FEBS Lett 581: 3608-3615, 2007.

52. Mulero-Navarro S and Fernandez-Salguero PM: New trends in Aryl hydrocarbon receptor biology. Front Cell Dev Biol 4: 45, 2016

53. Larigot L, Juricek L, Dairou J and Coumoul X: AhR signaling pathways and regulatory functions. Biochim Open 7: 1-9, 2018.

54. Bock KW: Aryl hydrocarbon receptor (AHR): From selected human target genes and crosstalk with transcription factors to multiple AHR functions. Biochem Pharmacol 168: 65-70, 2019

55. Josyula N, Andersen ME, Kaminski NE, Dere E, Zacharewski TR and Bhattacharya S: Gene co-regulation and co-expression in the aryl hydrocarbon receptor-mediated transcriptional regulatory network in the mouse liver. Arch Toxicol 94: 113-126, 2020.

56. Gu YZ, Hogenesch JB and Bradfield CA: The PAS superfamily: Sensors of environmental and developmental signals. Annu Rev Pharmacol Toxicol 40: 519-561, 2000.

57. Ge NL and Elferink CJ: A direct interaction between the aryl hydrocarbon receptor and retinoblastoma protein. Linking dioxin signaling to the cell cycle. J Biol Chem 273: 22708-22713, 1998.

58. Huang G and Elferink CJ: Multiple mechanisms are involved in Ah receptor-mediated cell cycle arrest. Mol Pharmacol 67: $88-96,2005$.
59. Marlowe JL, Knudsen ES, Schwemberger S and Puga A: The aryl hydrocarbon receptor displaces p300 from E2F-dependent promoters and represses $\mathrm{S}$ phase-specific gene expression. J Biol Chem 279: 29013-29022, 2004

60. Elferink CJ, Ge NL and Levine A: Maximal aryl hydrocarbon receptor activity depends on an interaction with the retinoblastoma protein. Mol Pharmacol 59: 664-673, 2001.

61. Jackson DP, Li H, Mitchell KA, Joshi AD and Elferink C: Ah receptor-mediated suppression of liver regeneration through NC-XRE-driven p21Cip1 expression. J Mol Pharmacol 85: 533-541, 2014.

62. Vogel CF, Sciullo E and Matsumura F: Involvement of RelB in aryl hydrocarbon receptor-mediated induction of chemokines. Biochem Biophys Res Commun 363: 722-726, 2007.

63. Tian Y, Ke S, Denison M, Rabson A and Gallo M: Ah receptor and NF-kappaB interactions, a potential mechanism for dioxin toxicity. J Biol Chem 274: 510-515, 1999.

64. Hollingshead BD, Beischlag TV, Dinatale BC, Ramadoss P and Perdew GH: Inflammatory signaling and aryl hydrocarbon receptor mediate synergistic induction of interleukin 6 in MCF-7 cells. Cancer Res 68: 3609-3617, 2008.

65. Kim DW, Gazourian L, Quadri SA, Romieu-Mourez R, Sherr DH and Sonenshein GE: The RelA NF-kappaB subunit and the aryl hydrocarbon receptor (AhR) cooperate to transactivate the c-myc promoter in mammary cells. Oncogene 19: 5498-5506, 2000.

66. Yeager RL, Reisman SA, Aleksunes LM and Klaassen CD: Introducing the 'TCDD-inducible AhR-Nrf2 gene battery'. Toxicol Sci 111: 238-246, 2009.

67. Wang L, He X, Szklarz GD, Bi Y, Rojanasakul Y, Ma Q The aryl hydrocarbon receptor interacts with nuclear factor erythroid 2-related factor 2 to mediate induction of $\mathrm{NAD}(\mathrm{P}) \mathrm{H}$ :quinoneoxidoreductase 1 by 2,3,7,8-tetrachlorodibenzo-p-dioxin. Arch Biochem Biophys 537: 31-38, 2013.

68. Zacharewski TR, Bondy KL, McDonell $\mathrm{P}$ and Wu ZF: Antiestrogenic effect of 2,3,7,8-tetrachlorodibenzo-p-dioxin on 17 beta-estradiol-induced pS2 expression. Cancer Res 54: 2707-2713, 1994

69. Gillesby BE, Stanostefano M, Porter W, Safe S, Wu ZF and Zacharewski TR: Identification of a motif within the 5' regulatory region of $\mathrm{pS} 2$ which is responsible for AP-1 binding and TCDD-mediated suppression. Biochemistry 36: 6080-6089, 1997.

70. Ohtake F, Fujii-Kuriyama Y and Kato S: AhR acts as an E3 ubiquitin ligase to modulate steroid receptor functions. Biochem Pharmacol 77: 474-484, 2009.

71. Peters JM, Narotsky MG, Elizondo G, Fernandez-Salguero PM, Gonzalez FJ and Abbott BD: Amelioration of TCDD-induced teratogenesis in aryl hydrocarbon receptor (AhR)-null mice. Toxicol Sci 47: 86-92, 1999.

72. Dere E, Lo R, Celius T, Matthews J and Zacharewski TR Integration of genome-wide computation DRE search, AhR ChIP-chip and gene expression analyses of TCDD-elicited responses in the mouse liver. BMC Genomics 12: 365-375, 2011.

73. Tijet N, Boutros PC, Moffat ID, Okey AB, Tuomisto J and Pohjanvirta R: Aryl hydrocarbon receptor regulates distinct dioxin-dependent and dioxin-independent gene batteries. Mol Pharmacol 69: 140-153, 2006.

74. Mitchell KA, Lockhart CA, Huang G and Elferink CJ: Sustained aryl hydrocarbon receptor activity attenuates liver regeneration. Mol Pharmacol 70: 163-170, 2006

75. Huang $\mathrm{G}$ and Elferink $\mathrm{CJ}$ : A novel nonconsensus xenobiotic response element capable of mediating aryl hydrocarbon receptor-dependent gene expression. Mol Pharmacol 81: 338-347, 2012

76. Harper JW, Elledge SJ, Keyomarsi K, Dynlacht B, Tsai LH, Zhang $\mathrm{P}$, Dobrowolski S, Bai C, Connell-Crowley L, Swindell E, et al: Inhibition of cyclin-dependent kinases by $\mathrm{p} 21$. Mol Biol Cell 6: 387-400, 1995.

77. Jackson DP, Joshi AD and Elferink CJ: Ah receptor pathway intricacies; signaling through diverse protein partners and DNA-motifs. Toxicol Res (Camb) 4: 1143-1158, 2015

78. Wilson SR, Joshi AD and Elferink CJ: The tumor suppressor Kruppel-like factor 6 is a novel aryl hydrocarbon receptor DNA binding partner. J Pharmacol Exp Ther 345: 419-429, 2013

79. Zhang W, Shields JM, Sogawa K, Fujii-Kuriyama Y and Yang VW: The gut-enriched Krüppel-like factor suppresses the activity of the CYP1A1 promoter in an Sp1-dependent fashion. J Biol Chem 273: 17917-17925, 1998.

80. Philipsen S and Suske G: A tale of three fingers: The family of mammalian $\mathrm{Sp} / \mathrm{XKLF}$ transcription factors. Nucleic Acids Res 27: 2991-3000, 1999 
81. Jeng YM and Hsu HC: KLF6, a putative tumor suppressor gene, is mutated in astrocytic gliomas. Int J Cancer 105: 625-629, 2003.

82. Andreoli V, Gehrau RC and Bocco JL: Biology of Krüppel-like factor 6 transcriptional regulator in cell life and death. IUBMB Life 62: 896-905, 2010.

83. Rubinstein M, Idelman G, Plymate SR, Narla G, Friedman SL and Werner $\mathrm{H}$ : Transcriptional activation of the insulin-like growth factor I receptor gene by the Kruppel-like factor 6 (KLF6) tumor suppressor protein: Potential interactions between KLF6 and p53. Endocrinology 145: 3769-3777, 2004.

84. Yang, L, Shi, P, Zhao, G, Xu J, Peng W, Zhang J, Zhang G, Wang X, Dong Z, Chen F and Cui H: Targeting cancer stem cell pathways for cancer therapy. Sig Transduct Target Ther 5: 8, 2020

85. Pearson JRD and Regad T: Targeting cellular pathways in glioblastoma multiforme. Sig Transduct Target Ther 2: 17040, 2017.

86. Murray IA, Patterson AD and Perdew GH: Aryl hydrocarbon receptor ligands in cancer: Friend and foe. Nat Rev Cancer 14: 801-814, 2014

87. Xue P, Fu J and Zhou Y: The aryl hydrocarbon receptor and tumor immunity. Front Immunol 9: 286, 2018.

88. Hayashibara T, Yamada Y, Mori N, Harasawa H, Sugahara K, Miyanishi T, Kamihira S and Tomonaga M: Possible involvement of aryl hydrocarbon receptor (AhR) in adult T-cel leukemia (ATL) leukemogenesis: Constitutive activation of AhR in ATL. Biochem Biophys Res Commun 300: 128-134, 2003.

89. Gentil M, Hugues P, Desterke C, Telliam G, Sloma I, Souza LEB Baykal S, Artus J, Griscelli F, Guerci A, et al: Aryl hydrocarbon receptor (AHR) is a novel druggable pathway controlling malignant progenitor proliferation in chronic myeloid leukemia (CML). PLoS One 13: e0200923, 2018.

90. Sanna S, Satta G, Padoan M, Piro S, Gambelunghe A, Miligi L, Ferri GM, Magnani C, Muzi G, Rigacci L, et al: Activation of the aryl hydrocarbon receptor and risk of lymphoma subtypes. Int J Mol Epidemiol Genet 8: 40-44, 2017.

91. Wang K, Li Y, Jiang YZ, Dai CF, Patankar MS, Song JS and Zheng J: An endogenous aryl hydrocarbon receptor ligand inhibits proliferation and migration of human ovarian cancer cells. Cancer Lett 340: 63-71, 2013

92. Perez AIL and Bradshaw TD: Exploring new molecular targets in advanced ovarian cancer: The aryl hydrocarbon receptor (AhR) and antitumor benzothiazole ligands as potential therapeutic candidates. Current Trends in Cancer Management, 2018

93. Tsay JJ, Tchou-Wong KM, Greenberg AK, Pass H and Rom WN: Aryl hydrocarbon receptor and lung cancer. Anticancer Res 33: 1247-1256, 2013.

94. Guerrina N, Traboulsi H, Eidelman DH and Baglole CJ: The aryl hydrocarbon receptor and the maintenance of lung health. Int J Mol Sci 19: 3882, 2018

95. Liu Z, Wu X, Zhang F, Han L, Bao G, He X and Xu Z: AhR expression is increased in hepatocellular carcinoma. $\mathrm{J}$ Mol Histol 44: 455-461, 2013

96. John K, Lahoti TS, Wagner K, Hughes JM and Perdew GH: The Ah receptor regulates growth factor expression in head and neck squamous cell carcinoma cell lines. Mol Carcinog 53: 765-776, 2014.

97. Louis DN, Perry A, Reifenberger G, von Deimling A, Figarella-Branger D, Cavenee WK, Ohgaki H, Wiestler OD, Kleihues P and Ellison DW: The 2016 World Health Organization classification of tumors of the central nervous system: A summary. Acta Neuropathol 131: 803-820, 2016.

98. Wesseling P and Capper D: WHO 2016 classification of gliomas. Neuropathol Appl Neurobiol 44: 139-150, 2018

99. Loeffler S, Fayard B, Weis J and Weissenberger J: Interleukin-6 induces transcriptional activation of vascular endothelial growth factor (VEGF) in astrocytes in vivo and regulates VEGF promoter activity in glioblastoma cells via direct interaction between STAT3 and Sp1. Int J Cancer 115: 202-213, 2005.

100. Botella LM, Sanz-Rodriguez F, Komi Y, Fernandez-L A, Varela E, Garrido-Martin EM, Narla G, Friedman SL and Kojima S: TGF-beta regulates the expression of transcription factor KLF6 and its splice variants and promotes co-operative transactivation of common target genes through a Smad3-Sp1-KLF6 interaction. Biochem J 419: 485-495, 2009.

101. Merk BC, Owens JL, Lopes MB, Silva CM and Hussaini IM: STAT6 expression in glioblastoma promotes invasive growth. BMC Cancer 11: 184, 2011.

102. Gu A, Ji G, Jiang T, Lu A, You Y, Liu N, Luo C, Yan W and Zhao P: Contributions of aryl hydrocarbon receptor genetic variants to the risk of glioma and PAH-DNA adducts. Toxicol Sci 128: 357-364, 2012
103. Li H xing, Peng $\mathrm{X}$ xiao, Zong Q, : Cigarette smoking and risk of adult glioma: A meta-analysis of 24 observational studies involving more than 2.3 million individuals. Onco Targets Ther 9: 3511-3523, 2016.

104. Maier MS, Legare ME and Hanneman WH: The aryl hydrocarbon receptor agonist 3,3',4,4',5-pentachlorobiphenyl induces distinct patterns of gene expression between hepatoma and glioma cells: Chromatin remodeling as a mechanism for selective effects. Neurotoxicology 28: 594-612, 2007.

105. Gramatzki D, Pantazis G, Schittenhelm J, Tabatabai G, Köhle C, Wick W, Schwarz M, Weller M and Tritschler I: Aryl hydrocarbon receptor inhibition downregulates the TGF-beta/Smad pathway in human glioblastoma cells. Oncogene 28: 2593-2605, 2009.

106. Pećina-Šlaus N, Kafka A, Tomas D, Marković L, Okštajner PK, Sukser V and Krušlin B: Wnt signaling transcription factors TCF-1 and LEF-1 are upregulated in malignant astrocytic brain tumors. Histol Histopathol 29: 1557-1564, 2014.

107. Djuzenova CS, Blassl C, Roloff K, Kuger S, Katzer A, Niewidok N, Günther N, Polat B, Sukhorukov VL and Flentje M Hsp90 inhibitor NVP-AUY922 enhances radiation sensitivity of tumor cell lines under hypoxia. Cancer Biol Ther 13: 425-434, 2012.

108. Seznec J, Silkenstedt B and Naumann U: Therapeutic effects of the Sp1 inhibitor mithramycin A in glioblastoma. J Neurooncol 101: 365-377, 2011.

109. Chiba Y, Todoroki M, Nishida Y, Tanabe M and Misawa M: A novel STAT6 inhibitor AS1517499 ameliorates antigen-induced bronchial hypercontractility in mice. Am J Respir Cell Mol Biol 41: 516-524, 2009.

110. Jin UH, Karki K, Cheng Y, Michelhaugh SK, Mittal S and Safe $\mathrm{S}$ : The aryl hydrocarbon receptor is a tumor suppressor-like gene in glioblastoma. J Biol Chem 294: 11342-11353, 2019.

111. de Robles P, Fiest KM, Frolkis AD, Pringsheim T, Atta C, St Germaine-Smith C, Day L, Lam D and Jette N: The worldwide incidence and prevalence of primary brain tumors: A systematic review and meta-analysis. Neuro Oncol 17: 776-783, 2015.

112. Girardi F, Allemani C and Coleman MP: Worldwide trends in survival from common childhood brain tumors: A systematic review. J Glob Oncol 5: 1-25, 2019.

113. Ostrom QT, Cioffi G, Gittleman H, Patil N, Waite K, Kruchko C and Barnholtz-Sloan JS: CBTRUS statistical report: Primary brain and other central nervous system tumors diagnosed in the United States in 2012-2016. Neuro Oncol 21 (Suppl 5): v1-v100, 2019

114. Gilbertson RJ and Ellison DW: The origins of medulloblastoma subtypes. Annu Rev Pathol 3: 341-365, 2008.

115. Yang ZJ, Ellis T, Markant SL, Read TA, Kessler JD, Bourboulas M, Schüller U, Machold R, Fishell G, Rowitch DH, et al: Medulloblastoma can be initiated by deletion of patched in lineage-restricted progenitors or stem cells. Cancer Cell 14: 135-145, 2008.

116. Rossi A, Caracciolo V, Russo G, Reiss K and Giordano A: Medulloblastoma: From molecular pathology to therapy. Clin Cancer Res 14: 971-976, 2008

117. Ramaswamy V and Taylor MD: Medulloblastoma: From myth to molecular. J Clin Oncol 35: 2355-2363, 2017.

118. Mulhern RK, Merchant TE, Gajjar A, Reddick WE and Kun LE: Late neurocognitive sequelae in survivors of brain tumours in childhood. Lancet Oncol 5: 399-408, 2004

119. Doussouki MEI, Gajjar A and Chamdine O: Molecular genetics of medulloblastoma in children: Diagnostic, therapeutic and prognostic implications. Future Neurol 14: FNL8, 2019

120. Miranda Kuzan-Fischer C, Juraschka K and Taylor MD Medulloblastoma in the molecular era. J Korean Neurosurg Soc 61: 292-301, 2018.

121. Dever DP and Opanashuk LA: The aryl hydrocarbon receptor contributes to the proliferation of human medulloblastoma cells Mol Pharmacol 81: 669-678, 2012.

122. Li Y, Guessous F, Johnson EB, Eberhart CG, Li XN, Shu Q, Fan S, Lal B, Laterra J, Schiff D and Abounader R: Functional and molecular interactions between the HGF/c-Met pathway and c-Myc in large-cell medulloblastoma. Lab Invest 88: 98-111, 2008.

123. Sarić N, Selby M, Ramaswamy V, Kool M, Stockinger B Hogstrand C, Williamson D, Marino S, Taylor MD, Clifford SC and Basson MA: The AHR pathway represses TGF $\beta$-SMAD3 signalling and has a potent tumour suppressive role in $\mathrm{SHH}$ medulloblastoma. Sci Rep 10: 148, 2020.

124. Johnsen JI, Dyberg C, Fransson S and Wickström M: Molecular mechanisms and therapeutic targets in neuroblastoma. Pharmacol Res 131: 164-176, 2018. 
125. Johnsen JI, Dyberg C and Wickström M: Neuroblastoma-A neural crest derived embryonal malignancy. Front Mol Neurosci 12: 9, 2019.

126. Steliarova-Foucher E, Colombet M, Ries LAG, Moreno F, Dolya A, Bray F, Hesseling P, Shin HY and Stiller CA; IICC-3 contributors: International incidence of childhood cancer, 2001-10: A population-based registry study. Lancet Oncol 8: 719-31, 2017.

127. Panagopoulou P, Georgakis MK, Baka M, Moschovi M, Papadakis V, Polychronopoulou S, Kourti M, Hatzipantelis E, Stiakaki E, Dana H, et al: Persisting inequalities in survival patterns of childhood neuroblastoma in Southern and Eastern Europe and the effect of socio-economic development compared with those of the US. Eur J Cancer 96: 44-53, 2018.

128. Kholodenko IV, Kalinovsky DV, Doronin II, Deyev SM and Kholodenko RV: Neuroblastoma origin and therapeutic targets for immunotherapy. J Immunol Res 2018: 7394268, 2018.

129. Allen-Rhoades W, Whittle SB and Rainusso N: Pediatric solid tumors of infancy: An overview. Pediatr Rev 39: 57-67, 2018.

130. Akahoshi E, Yoshimura $\mathrm{S}$ and Ishihara-Sugano $\mathrm{M}$ Over-expression of AhR (aryl hydrocarbon receptor) induces neural differentiation of Neuro2a cells: Neurotoxicology study. Environ Health 5: 24, 2006.

131. Wu PY, Liao YF, Juan HF, Huang HC, Wang BJ, Lu YL, Yu IS, Shih YY, Jeng YM, Hsu WM and Lee H: Aryl hydrocarbon receptor downregulates MYCN expression and promotes cell differentiation of neuroblastoma. PLoS One 9: 88795, 2014.

132. Latchney SE, Hein AM, O'Banion MK, DiCicco-Bloom E and Opanashuk LA: Deletion or activation of the aryl hydrocarbon receptor alters adult hippocampal neurogenesis and contextual fear memory. J Neurochem 125: 430-445, 2013.

133. Yang X, Liu D, Murray TJ, Mitchell G C, Hesterman EV, Karchner SI, Merson RR, Hahn ME and Sherr DH: The aryl hydrocarbon receptor constitutively represses c-myc transcription in human mammary tumor cells. Oncogene 24: 7869-7881, 2005.

134. Puga A, Barnes SJ, Dalton TP, Chang Cy, Knudsen ES and Maier MA: Aromatic hydrocarbon receptor interaction with the retinoblastoma protein potentiates repression of E2F-dependent transcription and cell cycle arrest. J Biol Chem 275: 2943-2950, 2000.
135. Wu PY, Chuang PY, Chang GD, Chan YY, Tsai TC, Wang BJ, Lin KH, Hsu WM, Liao YF and Lee H: Novel endogenous ligands of aryl hydrocarbon receptor mediate neural development and differentiation of neuroblastoma. ACS Chem Neurosci 10: 4031-4042, 2019.

136. Peters JC: Tryptophan nutrition and metabolism: An overview. In: Kynurenine and Serotonin Pathways: Progress in Tryptophan Research. Schwarcz R, Young SN and Brown RR (eds). Plenum Press Div Plenum Publishing Corp., New York, pp345-358, 1991.

137. Guillemin GJ, Cullen KM, Lim CK, Smythe GA, Garner B, Kapoor V, Takikawa O and Brew BJ: Characterization of the kynurenine pathway in human neurons. J Neurosci 27: 12884-12892, 2007.

138. Coggan SE, Smythe GA, Bilgin A and Grant RS: Age and circadian influences on picolinic acid concentrations in human cerebrospinal fluid. J Neurochem 108: 1220-1225, 2009.

139. Adams S, Braidy N, Bessede A, Brew BJ, Grant R, Teo C and Guillemin GJ: The kynurenine pathway in brain tumor pathogenesis. Cancer Res 72: 5649-5657, 2012.

140. Ye ZC and Sontheimer H: Glioma cells release excitotoxic concentrations of glutamate. Cancer Res 59: 4383-4391, 1999.

141. Opitz CA, Litzenburger UM, Sahm F, Ott M, Tritschler I, Trump S, Schumacher T, Jestaedt L, Schrenk D, Weller M, et al: An endogenous tumour-promoting ligand of the human aryl hydrocarbon receptor. Nature 478: 197-203, 2011.

142. Zhang S, Qin C and Safe SH: Flavonoids as aryl hydrocarbon receptor agonists/antagonists: Effects of structure and cell context. Environ Health Perspect 111: 1877-1882, 2003.

143. Kaiser H, Parker E and Hamrick MW: Kynurenine signaling through the aryl hydrocarbon receptor: Implications for aging and healthspan. Exp Gerontol 130: 110797, 2019. 